\title{
Effect of coal-over-coal reburn on furnace temperature and heat flux distributions in $1 \mathrm{MW}$ tangentially fired furnace
}

\author{
Sen $\mathrm{Li}^{\mathrm{a}, *}$, Tongmo Xu ${ }^{\mathrm{b}, 1}$, Qulan Zhou ${ }^{\mathrm{b}, 1}$, Houzhang Tan ${ }^{\mathrm{b}, 1}$, Shien Hui ${ }^{\mathrm{b}, 1}$ \\ a Institute of Mechanics, Chinese Academy of Sciences, No.15 Beisihuanxi Road, Beijing 100080, China \\ ${ }^{\mathrm{b}}$ State Key Laboratory of Multiphase Flow in Power Engineering, Xi'an Jiaotong University, 28 Xian Ning Road, Xi'an 710049, China
}

\section{A R T I C L E I N F O}

Article history:

Received 7 December 2008

Received in revised form

9 July 2009

Accepted 9 July 2009

Available online 30 July 2009

Keywords:

Coal reburn

Temperature distribution

Furnce wall

Heat flux

\begin{abstract}
A B S T R A C T
The furnace temperature and heat flux distributions of $1 \mathrm{MW}$ tangentially fired furnace were studied during coal-over-coal reburn, and the influences of the position of reburn nozzle and reburn fuel fraction on furnace temperature and heat flux distributions were investigated. Compared with the baseline, the flue gas temperature is $70-90{ }^{\circ} \mathrm{C}$ lower in primary combustion and $130-150{ }^{\circ} \mathrm{C}$ higher at furnace exit, and the variations of the flue gas temperature distributions along furnace height are slower. The temperature distribution along the width of furnace wall decreases with the increase of the relative furnace height. In the primary combustion zone and the reburn zone, the temperature and heat flux distributions of furnace wall are much non-uniform and asymmetric along the width of furnace wall, those of furnace wall in the burnout zone are relatively uniform, and the temperature non-uniformity coefficients of the primary combustion zone, the reburn zone and the burnout zone are $0.290,0.100$ and 0.031 , respectively. (C) 2009 Elsevier Masson SAS. All rights reserved.
\end{abstract}

\section{Introduction}

The requirements for environmental protection are increasingly strict, especially for coal-fired utility boiler. Therefore, low pollutant emissions must be considered in the design of a coal-fired utility boiler. Fuel reburn is an effective low- $\mathrm{NO}_{\mathrm{x}}$ combustion technology, and it is different from conventional combustion. Fuel reburn is a three-step combustion: in the first step the main fuel (usually coal) is burnt completely under oxidizing atmosphere, and the combustion zone is called as primary combustion zone; in the second step reburn fuel is injected into the furnace above the primary combustion zone to develop reducing atmosphere for $\mathrm{NO}_{\mathrm{x}}$ reduction, and the combustion zone is called as reburn zone; the third step over-fire air (OFA) is injected into the furnace above the reburn zone to oxidize carbon monoxide, hydrogen and any remaining unburned char coming from the reburn zone, and the combustion zone is called as burnout zone $[1,2]$. Reburn fuel can be any of three basic fossil fuel types: coal, natural gas, or oil. Compared with natural gas reburn and oil reburn for $\mathrm{NO}_{\mathrm{x}}$ reduction, coal reburn is economical low- $\mathrm{NO}_{\mathrm{x}}$ combustion technology. Since main fuel in the primary combustion is coal, the low- $\mathrm{NO}_{\mathrm{x}}$ combustion technology is called as coal-over-coal reburn (COCR)

\footnotetext{
* Corresponding author. Tel./fax: +86 1082544231

E-mail address: lisen@imech.ac.cn (S. Li).

1 Tel./fax: +86 2982668784
}

when coal is used as reburn fuel. COCR often causes the increase of unburned carbon in fly ash $[3,4]$. At the same time, compared with conventional combustion, COCR alters furnace heat flux distribution owing to the three-step combustion. Therefore, in terms of boiler efficiency, performance reliability and low- $\mathrm{NO}_{\mathrm{x}}$ emission, the following specific requirements for the COCR furnace design must be considered: (1) proper unburned carbon in fly ash and $\mathrm{CO}$ emission; (2) low- $\mathrm{NO}_{\mathrm{x}}$ emission; (3) proper flue gas temperature at furnace exit; (4) no extreme peak in the heat flux distribution of furnace wall.

Since furnace configuration design effects $\mathrm{NO}_{\mathrm{x}}$ emission [5], and thus, the investigation of the influences of COCR on boiler performance is necessary for the optimum design of the COCR boiler configuration. Many researchers have investigated the influences of some variables on $\mathrm{NO}_{\mathrm{x}}$ emissions during $\mathrm{COCR}$, and these important variables are as following: the reburn fuel fraction $\left(R_{\mathrm{ff}}\right)$; the position of reburn nozzle; the air stoichiometric ratio in primary combustion zone $\left(\mathrm{SR}_{1}\right)$; the air stoichiometry in reburn zone $\left(\mathrm{SR}_{2}\right)$ [2-7]. In practice, the furnace temperature distributions and furnace wall heat flux distributions are indispensable for boiler furnace design [8]. An important aspect of boiler design is related to the thermohydraulic behaviour of the furnace wall tubes. According to flue gas temperature distribution and the furnace wall heat flux distribution, the operating temperatures of evaporator heating surface can be accurately estimated to verify that tubes do not experience excessively high metal temperatures, which avoids resulting in tube failure due to overheating under practical 
operation [9]. Up to now, although the experiments of coal reburn have been conducted, most experiments were conducted in droptube furnaces and single burner furnaces [10-13]. Since the burner arrangement type and the furnace configuration of drop-tube furnaces and single burner furnaces are obviously different from those of utility boiler furnace, the experimental results of temperature distributions and furnace wall heat flux distributions in droptube furnaces and single burner furnaces cannot be used to guide utility boiler furnace design. In order to provide useful informations of furnace temperature and heat flux distributions for COCR boiler design, the experiment was conducted in a $1 \mathrm{MW}$ tangentially fired furnace with low $\mathrm{NO}_{\mathrm{x}}$ burners (LNB) and low $\mathrm{NO}_{\mathrm{x}}$ concentric firing system of biased primary air (CFS). The experimental results of $\mathrm{NO}_{\mathrm{x}}$ and $\mathrm{CO}$ emissions and unburned carbon in fly ash are presented in reference [4]. The influences of the reburn fuel fraction and the position of reburn nozzle on the temperature and heat flux distributions of furnace were investigated in the paper. ShenMu coal (a Chinese bituminous coal) was used as both the main fuel and the reburn fuel.

\section{Test facility}

Fig. 1 is the scheme of the test facility for a $1 \mathrm{MW}$ (heat input power) PC furnace, and the test facility is a tangentially fired furnace, which is $4200 \mathrm{~mm}$ in height, $770 \mathrm{~mm}$ in width and $630 \mathrm{~mm}$ in depth. The burners were separated into two groups, the top group of burners was arranged on each corner of the furnace including one upper secondary air, one lower secondary air and one primary air, and the bottom group of burners was arranged on somewhere near the middle of furnace wall including reburn coal injection nozzles (port1, port2, port3 and port4) and OFA injection nozzles, as shown in Fig. 1. The relative height of reburn nozzle $\left(h^{\prime}\right)$ is defined by:
$h^{\prime}=\frac{h}{D_{\mathrm{h}}}$

where $h$ is the distance between reburn nozzle and upper secondary air burner, $D_{\mathrm{h}}$ is the hydraulic diameter of furnace crosssection, and it can be expressed as:

$D_{\mathrm{h}}=\frac{2 a b}{(a+b)}$

where $a$ and $b$ are the width and the length of furnace cross-section, respectively. The relative locations of the four ports are $0.26,0.45$, 0.68 and 0.94 , respectively.

The primary air and secondary air were injected from burners located in the four corners into the furnace at set angles to form imaginary circles in the furnace center, as shown in Fig. 2. Primary air nozzles and secondary air nozzles were laid out at different offset angles, and the combustion systems are called CFSII (concentric firing system of biased primary air). The CFS has many advantages: (1) The imaginary circle diameter of secondary air is larger than that of primary air, and thus the outer concentric flow of air provides an oxidizing atmosphere near the boiler wall surface. In oxidizing atmosphere, the existing form of $\mathrm{Fe}$ is $\mathrm{Fe}_{2} \mathrm{O}_{3}$ in ash, and ash melting temperature does not decrease. In the meantime, the outer concentric flow of air can prevent combusting coal particles from scouring furnace wall surface. Therefore, the CFS can prevent furnace wall surface slagging. (2) The inner concentric zone and the outer concentric zone at furnace cross-section are in fuel-rich atmosphere and air-rich atmosphere, respectively. The mixing of fuel with air and combustion is delayed so as to reduce local peak temperature, and then thermal- $\mathrm{NO}_{\mathrm{x}}$ formation is reduced. (3) The CFS can also provide the fuel-nitrogen compounds a greater residence time in fuel-rich atmosphere, and thus fuel- $\mathrm{NO}_{\mathrm{x}}$ formation is also reduced [14].

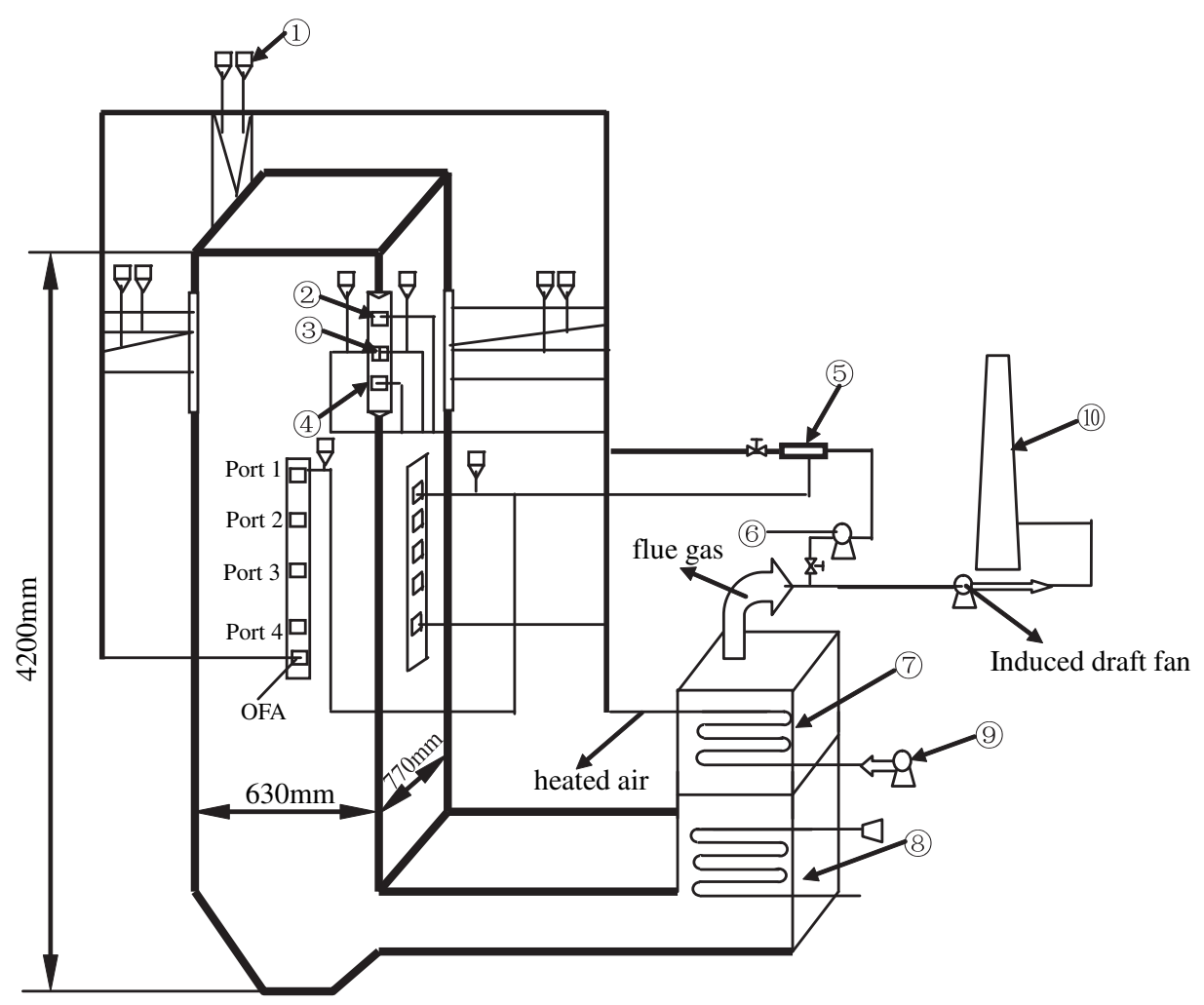

Fig. 1. The scheme of the test facility for a $1 \mathrm{MW}$ pulverized coal furnace. 


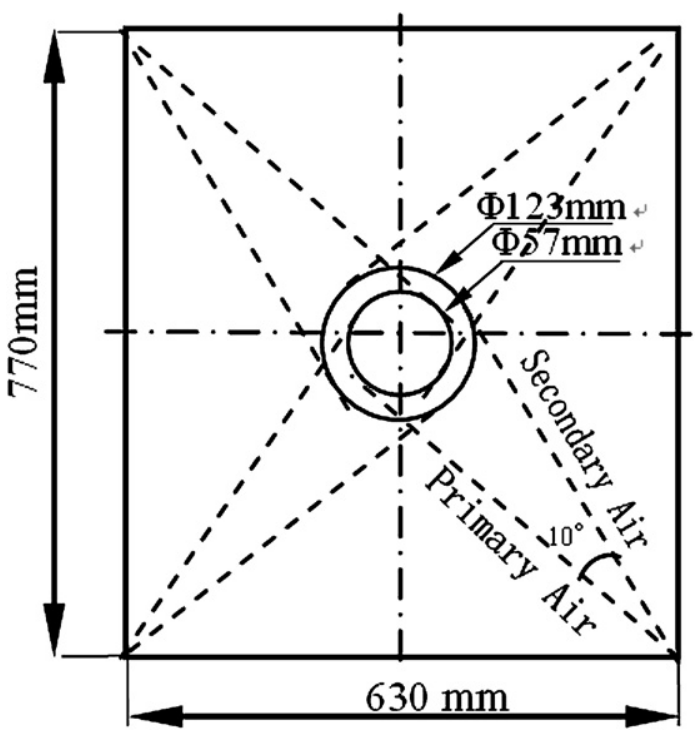

Fig. 2. The concentric firing system of biased primary air (CFSII).

Reburn burners and OFA burners form the wall tangentiallyfiring system (WTFS), which can increase the uniform temperature of wall surface and can prevent furnace surface slagging and fouling in reburn zone [15], as shown in Fig. 3.

The primary air was separated into two streams by a plate added in the pulverized coal pipe which was horizontal bias combustion burner. Two pulverized coal feeders were installed in each corner, which fed two pulverized coal streams into the primary air separately to form horizontal bias combustion. One pulverized coal feeder was installed each wall to feed coal into reburn nozzle. The twelve feeders were calibrated using the measuring weight method for various operating conditions, and the pulverized coal feeding rate had an accuracy of $\pm 3.5 \%$ of the measured value.

In the experiment, primary fuel and reburn fuel were the same kind of coal, ShenMu coal, a Chinese bituminous coal. The proximate and ultimate analysis data are given in Table 1. During coal reburn experiment, the total fuel flow rate was kept constant $(0.0282 \mathrm{~kg} / \mathrm{s})$ with changes in the amount of fuel sent to the primary and reburn zones, and the total air flow rate was also kept

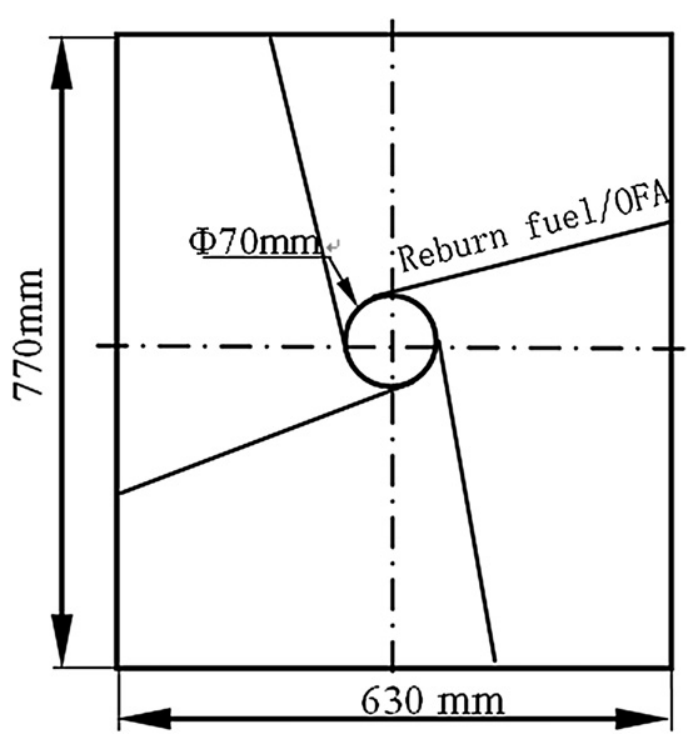

Fig. 3. The scheme of the wall tangentially-firing system (WTFS).
Table 1

Proximate analysis and ultimate analysis of dry coal

\begin{tabular}{|c|c|c|c|c|}
\hline \multicolumn{5}{|c|}{ Proximate analysis, wt \% (as air-dry) } \\
\hline Moisture & Ash & Volatility & Fixed carbon & Net heating $\left(\mathrm{kJ} \mathrm{kg}^{-1}\right)$ \\
\hline 2.6 & 6.56 & 32.76 & 58.08 & 28,370 \\
\hline \multicolumn{5}{|c|}{ Ultimate analysis, wt \% (as air-dry) } \\
\hline Carbon & Hydrogen & Oxygen & Nitrogen & Sulphur \\
\hline 73.63 & 4.54 & 11.38 & 0.95 & 0.34 \\
\hline
\end{tabular}

constant $(0.3087 \mathrm{~kg} / \mathrm{s})$ with changes in the amount of primary air, reburn air and OFA. The fuel and air distributions are given in Table 2. In order to obtain an efficient mixing of reburning flow with flue gas flow in furnace, reburn air mixed with a part of flue gas taken from economizer exit by flue gas recirculation fan to carry reburn coal into furnace (as shown in Fig. 1), and the oxygen concentration of reburn flow was $14 \%$. The OFA was pure air.

The flue gas temperatures of furnace center were measured by water-cooled suction pyrometer which consists of thermocouple part, radiation shield cap and water-cooling suction casing. Platinum-rhodium thermocouple, which can measure temperatures from 0 to $1600^{\circ} \mathrm{C}$, was placed within a 4 -mm diameter corundum sheath. The suction pyrometer is shielded by three concentric ceramic caps to minimize the radiative exchange with the surrounding surfaces or flames. These measure reduced the error obtained by using a bare thermocouple by over $95 \%$. Since the cross-section of furnace can be approximately regarded as a square, the heat transfer conditions of each furnace wall are similar. Therefore, the temperature distributions of furnace rear wall were only investigated in the experiment. Furnace wall temperatures were measured by $\mathrm{Ni}-\mathrm{Cr}$ and $\mathrm{Ni}-\mathrm{Si}$ thermocouples immersed in the inner wall, and the temperature measurement positions of rear furnace wall are shown in Fig. 4. The measurement accuracy of Ni$\mathrm{Cr}$ and $\mathrm{Ni}-\mathrm{Si}$ thermocouple is $\pm 1{ }^{\circ} \mathrm{C}$ at $0-1370{ }^{\circ} \mathrm{C}$.

In the furnace, flame flow is down from top to bottom, downfired. Here, the down direction of flame flow is regard as the plus direction of furnace height. In order to indicate temperature measurement position, the relative height of furnace $(Z)$ and the relative width of furnace wall $(X)$ are defined as follows:

$Z=\frac{Z}{D_{\mathrm{h}}}$

$X=\frac{x}{a}$

where $z$ is the distance between a certain furnace center and the location of upper secondary air burner; $x$ is the distance between a certain location of furnace rear wall and the right corner of furnace rear wall along the width; $a$ is the width of furnace rear wall, $770 \mathrm{~mm}$. Twenty-two of $\mathrm{Ni}-\mathrm{Cr}$ and $\mathrm{Ni}$-Si thermocouples were immersed in the rear furnace inner wall, as shown in Fig. 4.

\section{Results and discussions}

In order to investigate the influences of COCR on the furnace temperature distributions, the combustion test without coal

Table 2

Fuel flow rate and air flow rate.

\begin{tabular}{lllllll}
\hline$R_{\mathrm{ff}} \%$ & \multicolumn{2}{l}{ Coal flow rate, $\mathrm{kg} / \mathrm{s}$} & & \multicolumn{2}{l}{ Air flow rate, $\mathrm{kg} / \mathrm{s}$} \\
\cline { 2 - 3 } \cline { 5 - 6 } & Primary fuel & Reburn fuel & & Primary air & Reburn air & OFA \\
\hline 15 & 0.02397 & 0.00423 & & 0.239609 & 0.02225 & 0.046839 \\
20 & 0.02256 & 0.00564 & & 0.225514 & 0.034364 & 0.048819 \\
25 & 0.02115 & 0.00705 & & 0.21142 & 0.046479 & 0.050799 \\
\hline
\end{tabular}


reburning was taken as the baseline, the air stoichiometric ratio of which was 1.15 , and the total fuel flow rate was kept same as that of the reburn experiment.

\subsection{The flue gas temperature distributions of furnace center}

In the COCR experiment, the influences of reburn fuel fraction $\left(R_{\mathrm{ff}}\right)$ and the relative location of reburn nozzle $\left(h^{\prime}\right)$ on the flue gas temperature distributions of furnace center were investigated, and the results are shown in Figs. 5-7. In the process of coal reburning, the temperature of flue gas is $70-90^{\circ} \mathrm{C}$ lower in primary combustion zone $(Z=-0.43-0.26), 130-50{ }^{\circ} \mathrm{C}$ higher at the furnace exit as compared to the baseline. The reasons for the differences of temperature distributions between COCR and the baseline are as follows: (1) owing to coal reburn diverting a portion of the fuel from primary combustion zone to reburn combustion zone, the amount of fuel in primary combustion zone decreases, and it leads to the decrease of the flue gas temperature in the primary combustion zone as compared with the baseline; (2) reburn fuel combustion is delayed above the primary combustion zone, and it leads to the increase of flue gas temperature at furnace exit as compared with the baseline.

Compared with the baseline, the variations of flue gas temperature along the furnace height are slower, as shown in Figs. 5-7. Owing to coal reburn diverting a portion of the fuel from primary combustion zone to reburn zone, the combustion flame is prolonged in furnace, and it makes the combustion volumetric thermal load vary slower. Therefore, the variations of the flue gas temperature along the furnace height are slower during coal reburning.

With the increase of reburn nozzle position, the variation of flue gas temperature in primary combustion zone $(Z=-0.43-0.26)$ is not notable, but that in burnout zone $(Z=-0.94-4.6)$ is notable. Increasing the position of reburn nozzles along furnace height

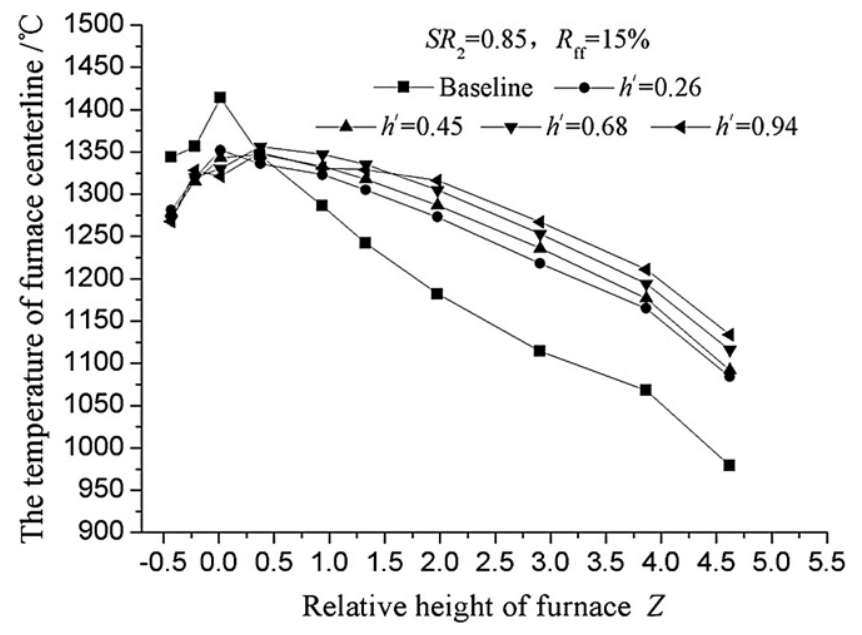

Fig. 5. The temperature distributions of furnace center at $R_{\mathrm{ff}}=15 \%$.

makes the reburn coal combustion delayed, and a large amount of unburned char continues to combust in burnout zone. Therefore, with the increase of the reburn nozzle position, the flue gas temperature of burnout zone $(Z=-0.94-4.6)$ increases, as shown in Figs. 5-7.

According to above experimental results, in the boiler design, some important factors need to be considered as follows:

(1) Owing to the high temperature flue gas in reburn zone and burnout zone, coal with low ash melting temperature used as reburn fuel easily causes ash-slagging on furnace wall. Therefore, the characteristics of reburn coal are important for the furnace design.

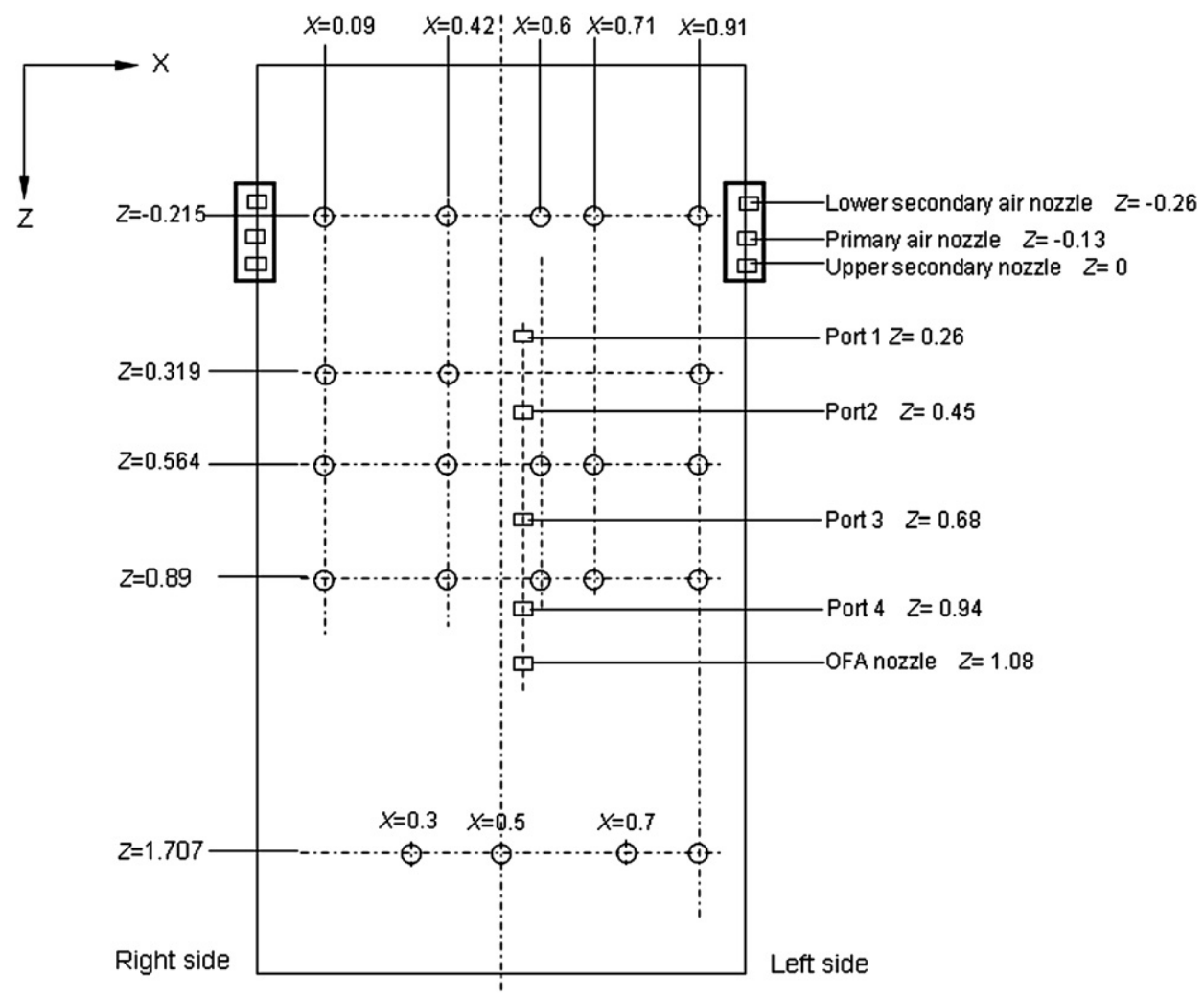

Fig. 4. The scheme of measurement position of temperature in rear furnace wall. 


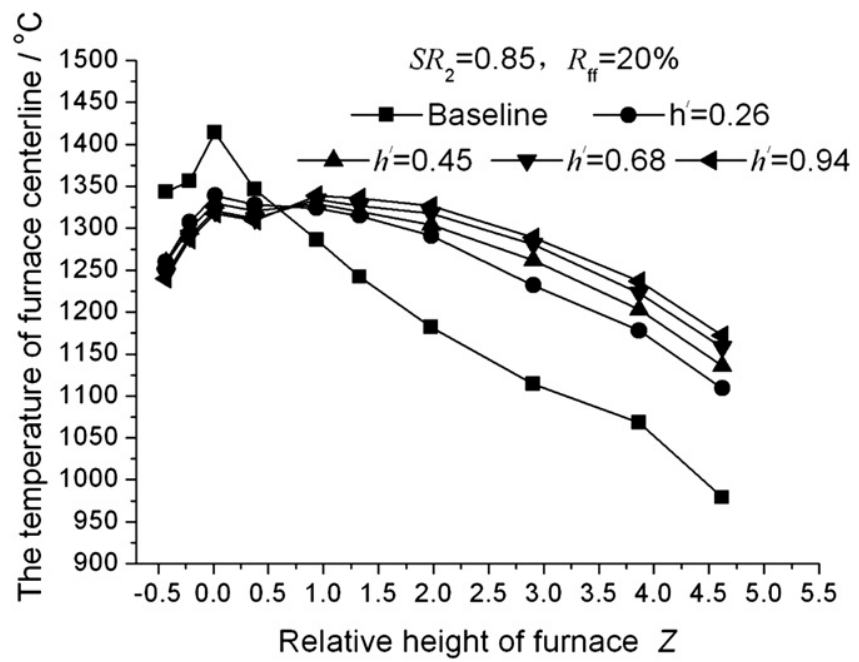

Fig. 6. The temperature distributions of furnace center at $R_{\mathrm{ff}}=20 \%$.

(2) The flue gas temperature distributions of COCR along furnace height are apparently different from that of the baseline, and it indicates that heat load distributions of COCR furnace are also different from that of the baseline. Therefore, in the design of furnace heating surface, the differences of heat load distributions of the three combustion zones (primary combustion zone, reburn zone and burnout zone) need to be noticed.

(3) Since the combustion delay of reburn coal causes the increase of flue gas temperature at furnace exit, unburned carbon in fly ash, and CO emission [4], the residence time of flue gas in furnace needs to be increased. To ensure adequate residence time for burnout and low volumetric heat release rate of furnace for low $\mathrm{NO}_{\mathrm{x}}$ formation, a large volume furnace design with expanses of water-cooled walls is indispensable.

\subsection{The temperature distributions of furnace wall}

In furnace, flame temperature is higher than $1000^{\circ} \mathrm{C}$ and radiative heat transfer is predominant. Therefore, the flue gas temperature distributions have a great influence on the temperature distribution of furnace wall. The experimental results show that the temperature distributions along the width of furnace rear

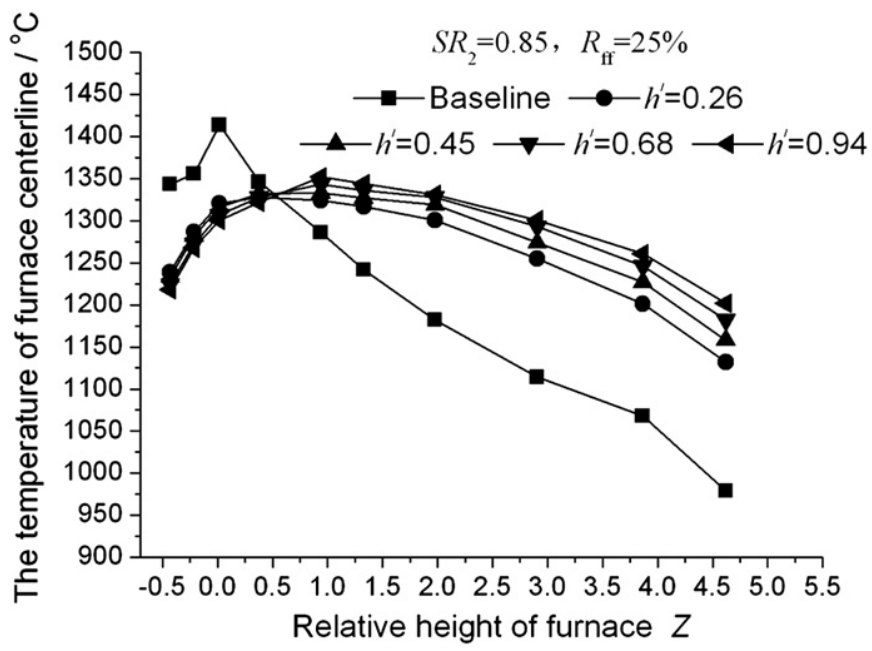

Fig. 7. The temperature distributions of furnace center at $R_{\mathrm{ff}}=25 \%$. wall are similar at $Z=0.39,0.56$ and 0.89 . The temperature distributions of furnace wall at $Z=-0.215,0.564$ and 1.707 are only presented, as shown in Figs. 8-10. The temperature contours of furnace wall are shown in Figs. 11-13.

In the primary combustion zone $(Z=-0.215)$, the temperature distributions of furnace wall are much non-uniform along the width of furnace wall, and they are also asymmetric. The temperatures on both sides of furnace wall are low, and the maximum temperature occurs on the furnace wall at the upstream of
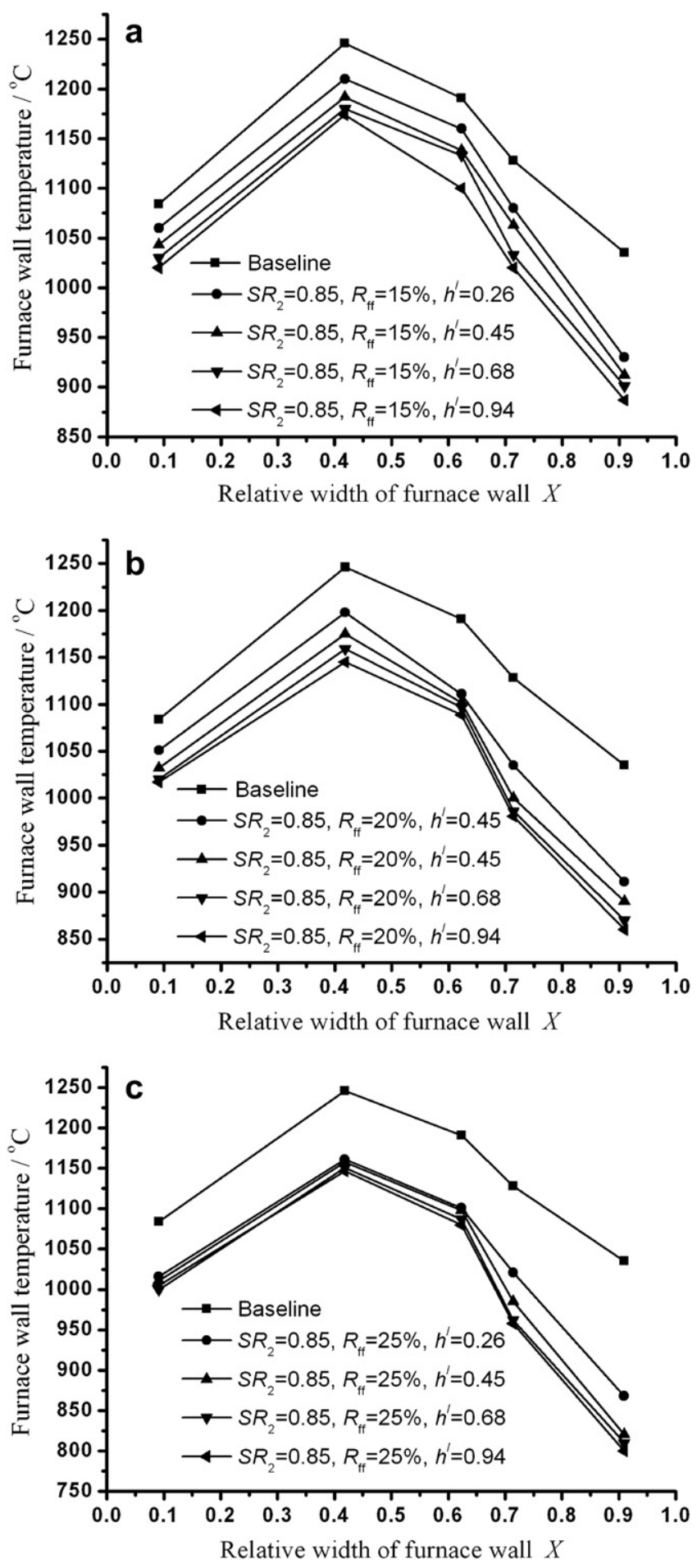

Fig. 8. Temperature distributions of the rear furnace wall along width at $Z=-0.215$. 

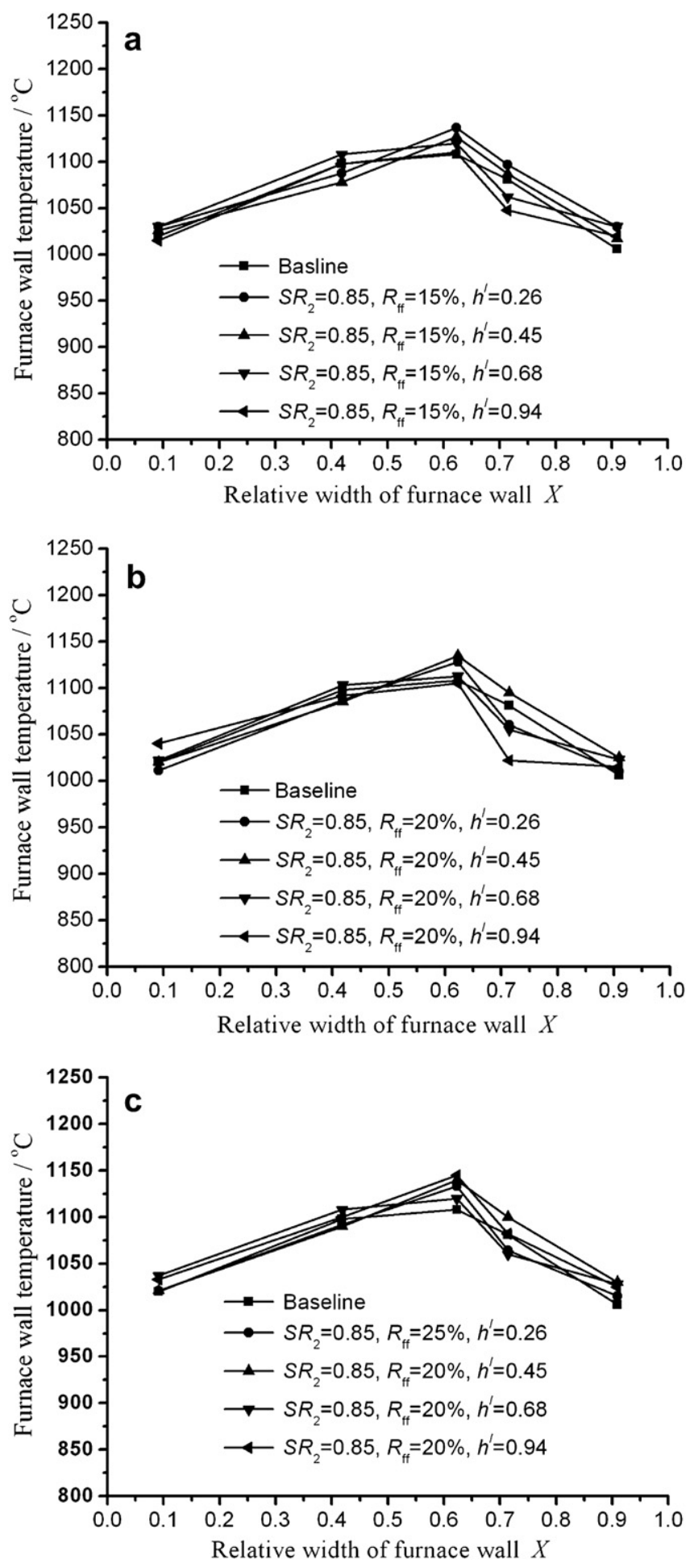

Fig. 9. Temperature distributions of the rear furnace wall along width at $Z=0.564$.

tangentially rotating combustion flame flow $(X<0.5)$. With the increase of the reburn nozzle position and reburn fuel fraction, furnace wall temperature decreases.

In the reburn combustion zone $(Z=0.564)$, the temperature distributions of furnace wall are also asymmetric, and the maximum temperature occurs on the furnace wall at the downstream of tangentially rotating combustion flame flow $(X>0.5)$. The influences of the reburn nozzle position and reburn fuel fraction on furnace wall temperature are not obvious.
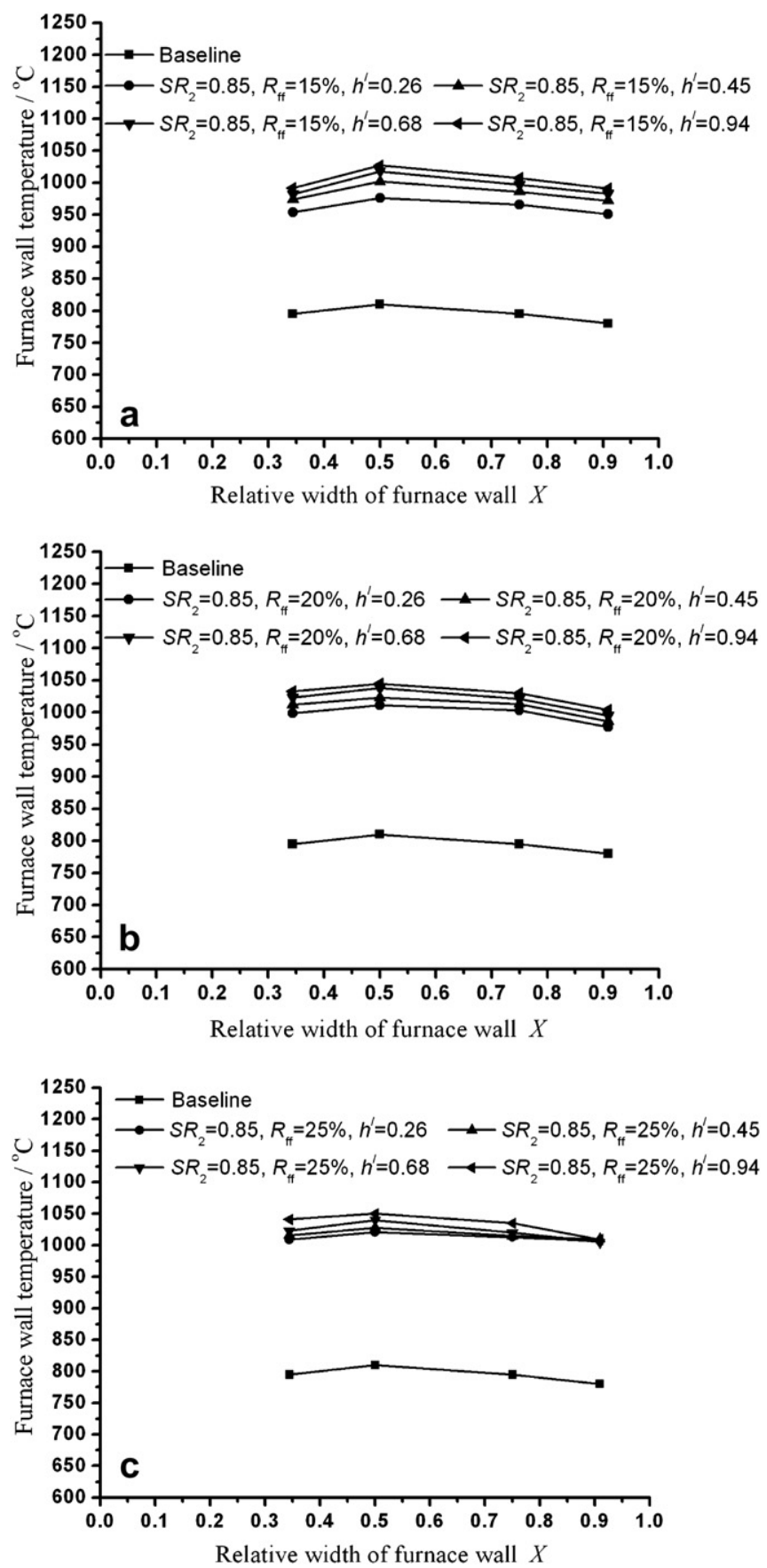

Fig. 10. Temperature distributions of the rear furnace wall along width at $Z=1.707$.

In the burnout zone $(Z=1.707)$, the temperature distributions of furnace wall are relatively uniform. With the increase of the reburn nozzle position and reburn fuel fraction, furnace wall temperature increases.

In Figs. 11-13, the temperature contours of furnace wall in primary reburning combustion zones are tight, and the temperature contours of furnace wall in burnout combustion zone are loose. The results indicate that the temperature gradients in primary and reburning combustion zones are large, and those in burnout zone are low. High temperature central region is almost invariant during coal reburning, where $Z$ is 0.3 or so. At fixed reburn position, with the increase of the reburn fuel fraction, the temperature of lower furnace wall decreases, and that of upper furnace wall increases. 

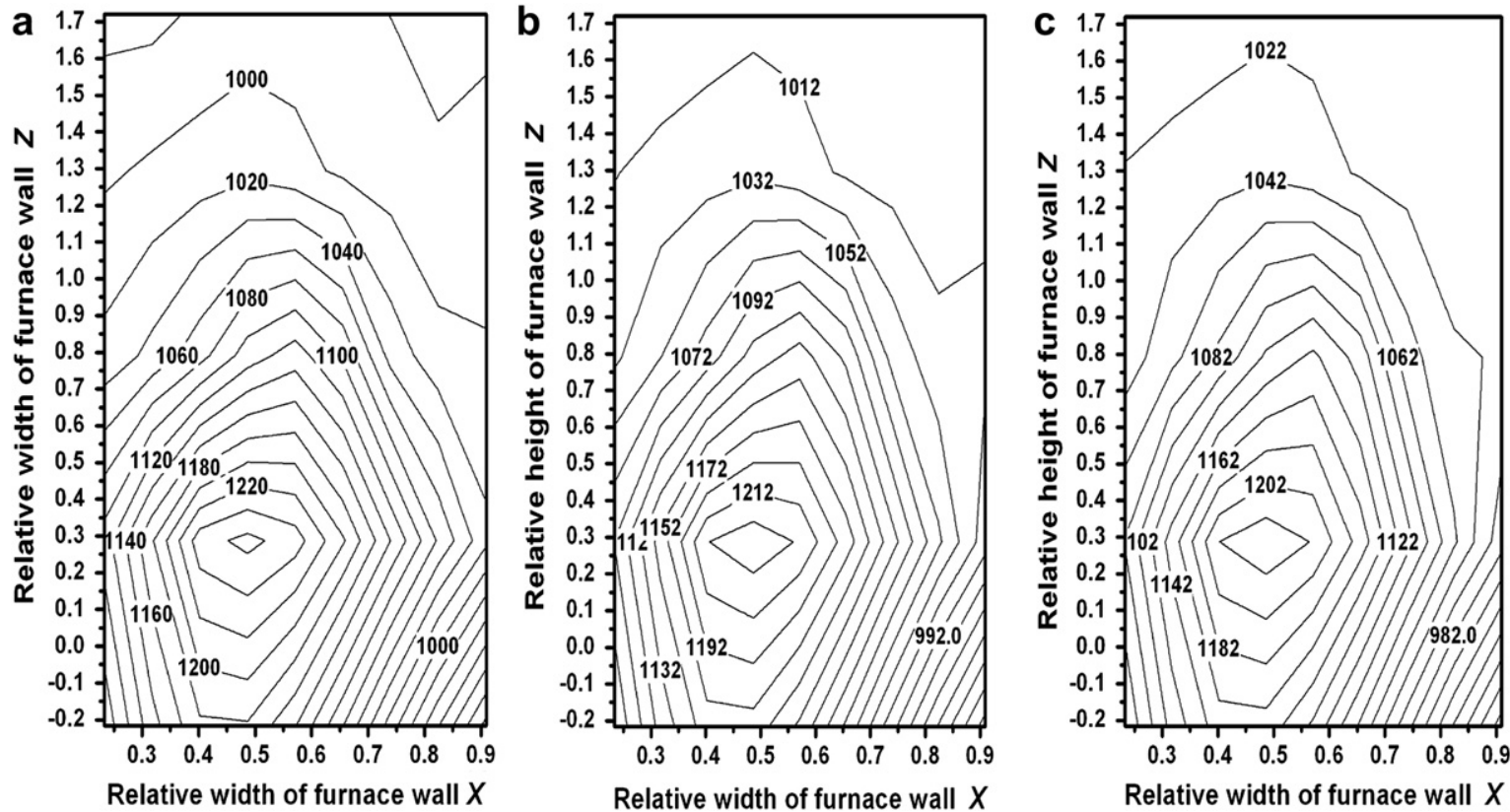

Fig. 11. Temperature contours of furnace wall at $\mathrm{SR}_{2}=0.85$ and reburn injection $h^{\prime}=0.26$.

In furnace, heat transfer and fuel combustion occur simultaneously, and all the factors related to heat transfer and combustion are coupled. Whenever the combustion process of fuel is changed, this results in different flame composition and different temperature distribution, and thus different heat absorption will be incurred, which means that the heat transfer process is varied. In the experiment, test coal is ShenMu coal, a Chinese bituminous coal, which is prone to ignition. Since the primary combustion zone is in oxidizing atmosphere, pulverized coal entrained by primary air ignites timely when it is injected into furnace, and combusting coal rapidly releases heat. Since the direction radiation intensity of the furnace wall near high flame flow is large, the furnace wall at the upstream of tangentially rotating combustion flame flow absorbs larger amount of heat as compared with that at the downstream of tangentially rotating combustion flame flow. Therefore, in the primary combustion zone, the maximum temperature occurs on the furnace wall at the upstream of tangentially rotating combustion flame flow, and the temperature distributions of furnace wall are much non-uniform and asymmetric.

Since reburn zone is in reducing atmosphere, the reburn coal combustion is delayed, which makes the furnace wall at the downstream of tangentially rotating combustion flame flow absorb much radiation heat. Therefore, in reburn zone, the maximum temperature occurs on the furnace wall at the downstream.

With the increase of the furnace height, the imaginary tangential circle diameter of flue gas flow enlarges, and thus the mixture of

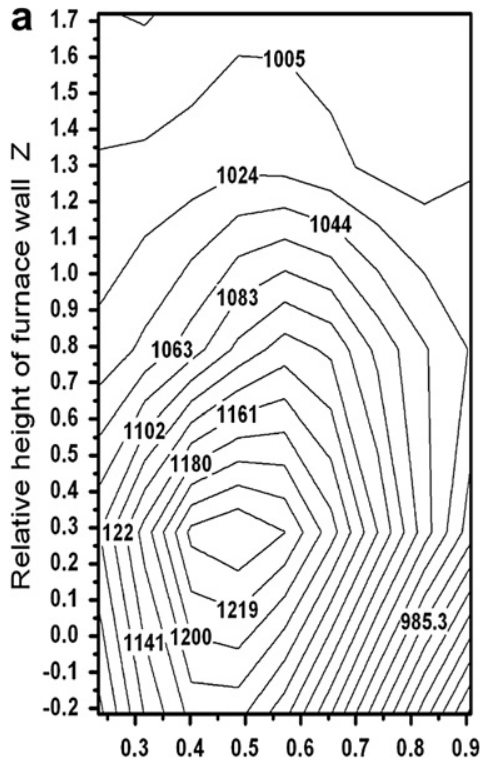

Relative width of furnace wall $X$

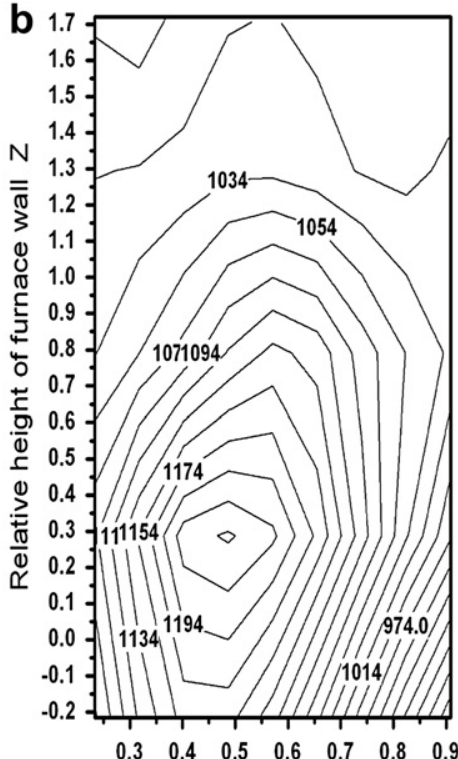

Relative width of furnace wall $X$

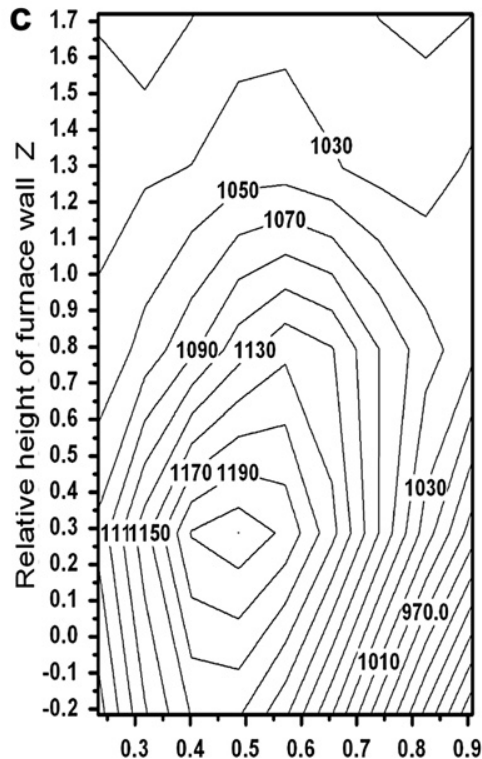

Relative width of furnace wall $X$

Fig. 12. Temperature contours of furnace wall at $\mathrm{SR}_{2}=0.85$ and reburn injection $h^{\prime}=0.45$. 

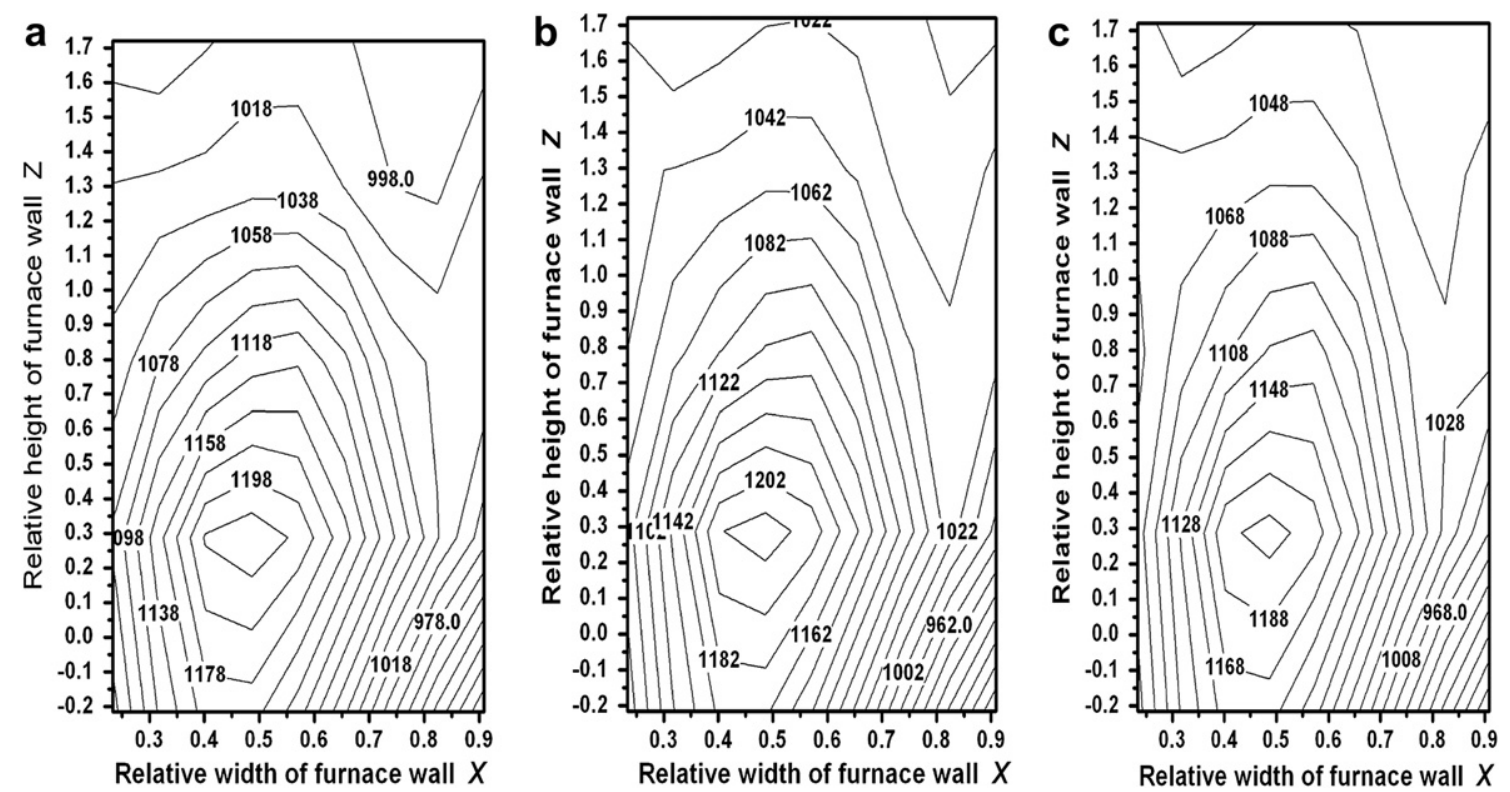

Fig. 13. Temperature contours of furnace wall at $\mathrm{SR}_{2}=0.85$ and reburn injection $h^{\prime}=0.68$.

flue gas temperature becomes ratively uniform in burnout zone [16]. In the meantime, most of fuel was combusted before flue gas entered burnout zone. Consequently, the temperature distribution of combustion flame flow in the burnout zone is uniform, which makes furnace wall absorb radiation heat uniformly, and thus the temperature distribution of furnace wall is uniform.

In order to investigate the non-uniform extent of temperature distributions of furnace wall, the temperature non-uniformity coefficient $(\delta)$ is defined:

$\delta=\frac{\left(t_{\max }-t_{\min }\right)}{t_{\mathrm{m}}}$

where $t_{\mathrm{max}}, t_{\mathrm{min}}$ and $t_{\mathrm{m}}$ are the maximum temperature, minimum temperature and average temperature of furnace wall, respectively.

The temperature non-uniformity coefficients of furnace wall are shown in Table 3, and this shows that the non-uniform extent of temperature distribution decreases with the increase of the furnace height. In the primary combustion zone, the non-uniform extent of temperature distribution is maximum.

\subsection{The heat flux distributions of furnace wall}

The non-uniform temperature distribution of furnace is the major cause of heat flux non-uniformity of furnace wall. Based on the calculation of furnace heat balance, the heat flux distribution of furnace wall was investigated. The furnace wall is composed of refractory bricks, and the heat absorbed by furnace wall is transferred to ambient. The local heat flux of furnace wall is calculated according to the temperature of furnace wall, ambient temperature and the heat transfer coefficient of furnace wall [17]. In the experiment, the total fuel flow rate and the total air flow rate kept constant, and unburned carbon in ash fly and CO concentration

Table 3

The non-uniform coefficients of temperature distribution of furnace wall.

\begin{tabular}{lrrr}
\hline Relative height of furnace wall $(Z)$ & -0.215 & 0.564 & 1.707 \\
Non-uniform coefficient $(\delta)$ & 0.290 & 0.100 & 0.031 \\
\hline
\end{tabular}

were investigated [4]. Therefore, the average heat flux of furnace wall is calculated according to the calculation of furnace heat balance. The relative heat flux of furnace wall can be calculated by:

$\tilde{q}=\frac{q}{\bar{q}}$

where $\tilde{q}, q$ and $\bar{q}$ are the relative heat flux, local heat flux and averaged heat flux of furnace wall, respectively.

In the experiment, since the furnace wall is composed of refractory bricks, the temperature distribution of furnace wall can reflect the heat flux distribution of furnace wall, and high temperature of furnace wall means high heat flux on local furnace wall. Therefore, the relative heat flux distributions of furnace rear wall are only presented when the relative height of reburn nozzle $\left(h^{\prime}\right)$ is 0.26 , as shown in Fig. 14. The mean heat flux $(\bar{q})$ is $34.47 \mathrm{~kW} /$ $\mathrm{m}^{2}$. The results show that: (1) The heat fluxes on both sides of furnace wall are low, and the heat flux distributions are asymmetric along furnace width; (2) In primary combustion zone $(Z=-0.43-$ 0.26 ), the variation of heat flux along furnace width is noticeably, and the distribution is much non-uniform; (3) With the increase of reburn fuel fraction, the heat flux of furnace wall in primary combustion zone $(-Z=-0.43-0.26)$ decreases, but that in burnout zone $(-Z>0.94)$ increases; (4) In the burnout zone, the heat flux distribution of furnace wall is relatively uniform.

In practical application, the temperature and heat flux distributions of furnace wall directly influence the stability and security of heating surface. For a natural circulation boiler, the temperature variances of furnace wall with different heat flux may result in different flow rates of water-cooled tubes. In the range of selfcompensation, if the heat flux varies greatly among the watercooled tubes, the circulating flow rate in the tubes with a very low heat flux may possibly be very low, even stagnation or flow reversal may occur, which impairs the reliability of the operation. For forced flow boiler, over-high heat flux of water-cooled tube may lead to heat transfer deterioration and tube failure due to deformation resulting from excessive temperature differences among adjacent tubes of membrane water-cooled wall. Therefore, in order to overcome above problems in the design of COCR boiler furnace heating surface, circulation circuits should be divided according to the 


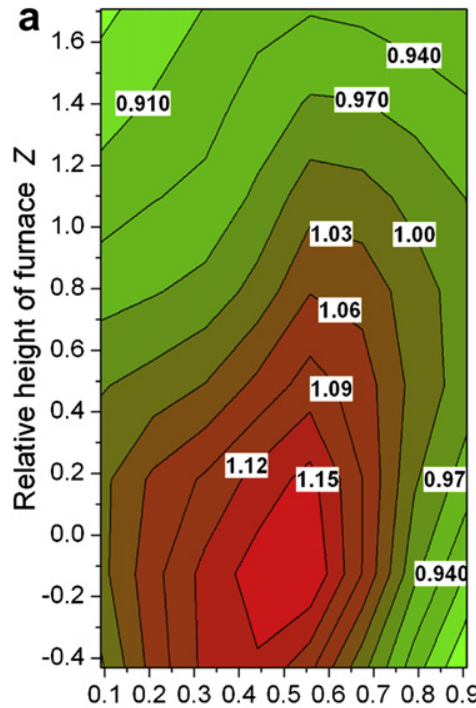

Relative width of furnace wall $X$

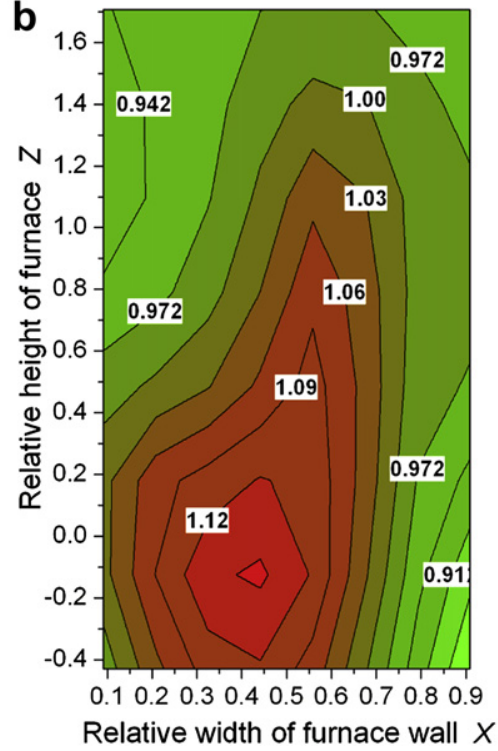

Fig. 14. Calculated relative heat flux contours of rear furnace wall at reburn injection $h^{\prime}=0.26$

differences of heat flux distributions. The water-cooled tubes should be divided into several panels, and the tubes in the same panel should have identical heat absorption and structure. The tubes in furnace corner should be classified into an independent panel.

\section{Conclusions}

The furnace temperature and heat flux distributions of $1 \mathrm{MW}$ tangentially fired furnace were studied during coal-over-coal reburn. The following conclusions can be drawn from the experimental results:

(1) During coal-over-coal reburn, as compared with the baseline, the flue gas temperature is $70-90{ }^{\circ} \mathrm{C}$ lower in primary combustion and $130-50{ }^{\circ} \mathrm{C}$ higher at the furnace exit, and the variations of the flue gas temperature along furnace height are slower.

(2) In the primary combustion zone and the reburn combustion zone, the temperature distributions of furnace wall are nonuniform and asymmetric along the width of furnace wall, and those in the burnout zone are relatively uniform.

(3) The non-uniformity coefficient of temperature distribution along the width of furnace wall decreases with the increase of the relative furnace height, and the temperature non-uniformity coefficients of the primary combustion zone, the reburn zone and the burnout zone are 0.290, 0.100 and 0.031, respectively.

(4) In the primary combustion zone and the reburn combustion zone, the temperature and heat flux distributions of furnace wall are much non-uniform and asymmetric along the width of furnace wall, those in the burnout zone are relatively uniform.

(5) According to the experimental results of coal-over-coal reburn, in boiler design, some important factors need to be considered as follows: ash-slagging on furnace wall, the change of furnace heat load along furnace height, the residence time of flue gas in furnace, and the layout of heating surface in the primary combustion zone.

\section{Acknowledgements}

Financial supports by Major State Basic Research Development Program of China (NO. 2005CB 221206) and China Natural Science
Foundation (50776099) are acknowledged. The authors would like to thank Dr. Ke Zhao, Dr. San Xue, Peng Sun, Ruwei Liu, Cheng Dong and Qinwei Fan for their help on this work.

\section{References}

[1] L.D. Smoot, S.C. Hill, H. Xu, $\mathrm{NO}_{\mathrm{x}}$ control through coal reburning, Progress in Energy and Combustion Science 24 (1998) 385-408.

[2] P.M. Maly, V.M. Zamansky, L. Ho, R. Payne, Alternative fuel reburning, Fuel 78 (1999) 327-334.

[3] EPA, Summary Report on Control of NOx Emissions by Reburning, US Environmental Protection Agency, 1996, EPA/625/R-96/001p. 17.

[4] S. Li, T.M. Xu, Q.L. Zhou, Optimization of coal reburning in a $1 \mathrm{MW}$ tangentially fired furnace, Fuel 86 (2007) 169-175.

[5] H. Kremer, F. May, S. Wirtz, The influence of furnace design on the NO formation in high temperature processes, Energy Conversion and Management 42 (2001) 937-952.

[6] P.J. Canning, R. Hill, Development of Coal-On Coal, DTI/Pub URN 02/900, (2002) pp. 1-7.

[7] H. Liu, E. Hampartsoumian, B.M. Gibbs, Evaluation of the optimal fuel characteristics for efficient NO reduction by coal reburning, Fuel 76 (1997) 985-993.

[8] C.H.E. Defu, Boilers-Theory, Design and Operation, first ed. Xi'an Jiaotong University Press, Xi'an, 2008.

[9] L.A. Payan-Rodriguez, A. Gallegos-Muñoz, G.L. Porras-Loaiza, M. Picon-Nuñez, Critical heat flux prediction for water boiling in vertical tubes of a steam generator, International Journal of Thermal Sciences 44 (2005) 179-188.

[10] E. Hampartsoumian, O.O. Folayan, W. Nimmo, B.M. Gibbs, Optimisation of $\mathrm{NO}_{\mathrm{x}}$ reduction in advanced coal reburning systems and the effect of coal type, Fuel 82 (2003) 373-384.

[11] S. Su, J. Xiang, L.S. Sun, Z.X. Zhang, X.X. Sun, C.G. Zheng, Numerical simulation of nitric oxide destruction by gaseous fuel reburning in a singleburner furnace, Proceedings of the Combustion Institute 31 (2007) 2795-2803.

[12] W. Kordylewski, W. Zacharczuk, T. Hardy, J. Kaczmarczyk, The effect of the calcium in lignite on its effectiveness as a reburn fuel, Fuel 84 (2005) $1110-1115$.

[13] T. Hardy, W. Kordylewski, Effectiveness of polish lignites as reburn fuels, Fuel 81 (2002) 837-840.

[14] DOE/NETL, The Advanced Tangentially Fired Combustion Techniques for the Reduction of Nitrogen Oxides $\left(\mathrm{NO}_{\mathrm{x}}\right)$ Emissions from Coal-Fired Boilers Demonstration Project, US Department of Energy and Nation Energy Technology Laboratory, 2000, DOE/NETL-2000/1122.

[15] H.Z. Tan, T.M. Xu, S.E. Hui, The experiment study of heat flux distribution in wall tangentially flame, Journal of Engineering Thermophysics 21 (2000) 525-528 (in Chinese).

[16] Y.G. Zhou, In-furnace flue-gas flow characteristics and selection of furnace height for a tangentially fired boiler, Journal of Engineering for Thermal Energy and Power 16 (2001) 46-48 (in Chinese).

[17] J. Taler, A method of determining local heat flux in boiler furnaces, International Journal of Heat and Mass Transfer 35 (1992) 1625-1634. 